homem dominar o universo e sobreviver à morte.

Trata-se principalmente aqui de mostrar a importância do texto literário, não apenas como forma de conhecimento, mas também como meio de ação, sem que para isso se perca a autonomia de criação artistica que lhe é inerente: se a expressão individual assume uma dimensão social - o que permite a abordagem sóciohistórica dos romances - ela é também e principalmente fruto de uma determinada consciência literária e criação de um estilo particular - no caso, o revolucionário, onde o idealismo estético se impõe e predomina.

Além de constituir importante reflexão sobre um mo-

mento histórico de importância capital em nosso século, esta obra fornece interessantes instrumentos para a análise do fenômeno histórico-literário, apresentando inovações aos métodos de teoria literária, na medida em que se insere no campo das pesquisas interdisciplinares.

Num momento de crises ameaçadoras como o que vivemos atualmente, uma análise tão sensivel dos horrores da Revolução e da necessidade do restabelecimento de determinados valores, como a que faz Malraux nesses romances, bem merece um ensaio que evidencie sua pertinência e suas repercussões.

\title{
POESIA ARCÁDICA PORTUgUeSA
}

\section{LÊNIA MÁRCIA DE MEDEIROS MONGELLI}

Coleção Literatura e Perspectiva, São Paulo, Global, 1986

Fazendo parte de programa mais amplo, sob direção do Prof. Dr. Massaud Moisés, esta obra pretende oferecer uma visão de conjunto da poesia do Arcadismo em Portugal.

Com este intuito, seleciona textos nem sempre facilmente encontráveis, de autores muitas vezes desconhecidos do grande público, como João Xavier de Matos, Filinto Elisio, Marquesa de Alorna etc. Em que pese a homogeneidade de visão de mundo típica dos poetas da se- gunda metade do século XVIII, a seleção permite detectar a nota distintiva de cada um, conduzindo à realidade pluriforme, prenhe de contradições, cujo centro é ocupado pela Revolução Francesa.

Os textos selecionados vêm precedidos e/ou acompanhados de: a) uma "Introdução" substancial, onde o Arcadismo é visto, de perspectiva histórica, na Europa e em Portugal; e, de perspectiva estilística, em seus componentes estéticos 
mais significativos; b/ estudo crítico e bibliografia comentada acerca de cada autor antologiado; c) glossário, que facilita a intelecção dos textos de estrutura arcaica; d) bibliografia geral comentada, simplificando o trabalho de pesquisa dos interessados.

\section{ESTRUTURA DAS ORGANIZAC̣ŌES TRADICIONAL, INOVADORA, MATRICIAL EDUARDO VASCONCELLOS}

\section{JAMES R. HEMSLEY}

São Paulo, Biblioteca Pioneira de Administração de Negócios, Editora da Universidade de São Paulo, 1986

O termo Matriz está cada vez mais fazendo parte da linguagem usual do administrador. Hoje, já há um corpo suficiente de conhecimentos sobre o assunto que permite a elaboração de um livro adaptado às características da realidade brasileira.

A estrutura matricial existe há muito tempo de forma implícita em muitos tipos de organização. Somente na década de 50 esta forma de estrutura foi formalizada e depois estudada por especialistas em Administração.

Muitas inovações em termos de técnicas gerenciais foram idealizadas por cientistas da Administrção e depois foram adaptadas $e$ implantadas no mundo empresarial. Com a Matriz deu-se o inverso, isto é, as empresas passaram a utilizá-la para atender às suas necessidades e mais tarde ela foi descoberta e estudada por pesquisadores da ciência administrativa.

A indústria aeroespacial caracteriza-se por:

- grandes projetos de complexa tecnologia;

- projetos interdisciplinares que necessitam da cooperação de especialistas de diferentes áreas técnicas para realização;

- pressões para cumprimento de prazos, orçamentos e padrões de qualidade.

As estruturas tradicionais não conseguiram responder de forma eficaz às características dos grandes projetos da indústria aeroespacial. Pouco a pouco, começou-se a usar uma forma estrutural que utilizava simultaneamente gerentes de 